6. Khoruzha L., Kyrychok V. Duhovno-moralne vyhovannia shkoliariv v Ukraini: dosvid ta shliakhy vdoskonalennia [Spiritual and moral education of schoolchildren in Ukraine: experience and ways of improvement] // Ridna shkola. - 2013. - № 4 - 5. - S. 26-32.

УАК 37.035-055.1/.2:[374:78]

\title{
МАРИСА ОСТАПЕНКО
}

ostaplora@ukr.net кандидат педагогічних наук, доцент, Київський національний університет культури і мистецтв м. Київ, вул. С. Коновальця, 36

\section{ПРОБАЕМИ СОЦІААІЗАЦІЇ ШКОАЯРІВ В УМОВАХ АИТЯЧОГО МУЗИЧНОГО КОАЕКТИВУ}

\begin{abstract}
Досліджено процес сочіалізації школярів в умовах дитячого музичного колективу. Розглянуто різні фактори соціалізації дітей та їх основні види (стихійна; відносно спрямована; сочіально-контрольована). Охарактеризовано прочес стимулювання творчої активності й реалізацію потреби у визнанні серед однолітків в процесі участі в дитячих музичних фестивалях. Висвітлено соціалізацію як складний проиес формування особистості дитини, особливо у шкільному підлітковому віці, становлення та формування ї̈ сутності та світогляду в умовах музичного колективу. Показано, що виховання школярів у музичному спрямуванні має за мету організовану діяльність для формування якостей особистості через організацію практичного творчого спілкування. Встановлено, що формування школярів в умовах дитячого музичного колективу відбувається в умовах соціального середовища та соціального спілкування, тут вирішальну роль відіграють мотивачія $i$ стимулювання творчої активності школярів. Обгрунтовано, щз творче спілкування в музичному дитячому колективі є могутнім внутрішнім стимулом для реалізації своїх здібностей у дитини, спонукає до самоствердження та завоювання авторитету в однолітків. Доведено, щзо тільки у згуртованому музичному колективі можна правильно і професійно організувати педагогічне керівництво творчим процесом.
\end{abstract}

Ключові слова: соціалізація дітей, дитячий музичний колектив, соціокультурний розвиток, музичний фестиваль, обдарованість, музичні здібності, креативність.

МАРИСА ОСТАПЕНКО

кандидат педагогических наук, доцент, Киевский национальный университет культуры и искусств г. Киев, ул. Е. Коновальца, 36

\section{ПРОБАЕМЫ СОЦИААИЗАЦИИ ШКОАЬНИКОВ В УСАОВИЯХ АЕТСКОГО МУЗЫКААЬНОГО КОААЕКТИВА}

Исследован процесс сочиализации школьников в условиях детского музыкального коллектива. Рассмотрены различные факторы соииализации детей, а также их основные виды (стихийная, относительно направленная и социально контролируемая). Охарактеризован проиесс симулирования творческой активности и реализации потребности в признании себя среди сверстников в процессе участия в детских музыкальных фестивалях. Социализация освещается как сложный процесс формирования личности ребенка, особенно в школьном подростковом возрасте, его становление, формирование и мировоззрения в условиях музыкального коллектива. Показано, что основная изель воспитания школьников в музыкальном направлении состоит $в$ организованной деятельности для формирования качеств личности с помощьью организации практического творческого общения. Установлено, что формирование школьников в детском музыкальном коллективе происходит в условиях соииальной среды и социиального общения, здесь решающую роль играют мотивация и стимулирование творческой активности школьников. Обосновано, что творческое общение в музыкальном детском коллективе является могучим внутренним стимулом для реализации своих способностей у ребенка, которое стимулирует к самоутверждению и завоеванию авторитета среди сверстников. Отмечено, что в сплоченном музыкальном коллективе можно правильно и профессионально организовать педагогическое руководство творческим проиессом. 
Ключевые слова: социализачия детей, детский музыкальный коллектив, социокультурное развитие, музыкальный фестиваль, одаренность, музыкальные способности, креативность.

\section{LARYSA OSTAPENKO}

$\mathrm{Ph}$. D. in pedagogy, associate professor, Kyiv National University of Culture and Arts Kyiv, Konovalets, 36 st.

\section{THE PROBLEMS OF SOCIALIZATION OF CHILDREN IN A CHILDREN'S MUSICAL GROUP}

The article studies the process of the socialization of children in a musical group. The author has studied diverse factors of the socialization of children and its types (spontaneous socialization; relatively controlled socialization and socially controlled socialization). The author has also given characteristics of creative activity stimulation and described the need to be accepted by peers being realized during the participation in children's music festivals. The notion of socialization was defined as a complex process of a child's personality development, especially during the school/teen age, whereby an individual acquires a personal identity and learns the norms, values, behavior, and social skills appropriate to his or her social position in the context of a musical group. Educational work conducted be teachers, family members and society contributes to this process. School education in terms of a musical group consists of activities organised in order to educate personality traits through the organization of practical creative communication. Schoolchildren's interpersonal relations are always based on social relations. It is proved that the personality development in a children's musical group is placed in social environment and social communication. The key role belongs here to the motivation and the incentive of the schoolchildren's creative activity. Creative communication in a children's musical group turns out to be a powerful inner stimulation for children to fulfil their abilities. It pushes a child towards selfassertion and the gain of authority among peers. The article proves that pedagogical guidance of the creative process can be led professionally only in a well-organised musical group.

Keywords: children's socialization, children's musical group, sociocultural development, music festival, giftedness, musical abilities, creativeness.

Гуманізація сучасного суспільства в Україні, його духовне і моральне оновлення зумовили формування внутрішнього світу особистості, іiі творчої активності і вільного прояву індивідуального креативного потенціалу. В зв’язку з цим суттєву значимість набуває сфера музичного мистецтва як джерело і ціль духовного становлення особистості.

Сучасна наукова думка розглядає мистецтво одним із важливих освітніх впливів на формування особистості дитини, іiі світогляду, духовного потенціалу. Воно має велике виховне та пізнавальне значення для людини, оскільки дозволяє їй значно розширити власний життєвий досвід, задовольняти свої зростаючі інтереси до оточуючого світу та соціуму, формує іï духовний світ. Мистецтво є одним із генеральних факторів в процесі естетичного виховання особистості.

Мета статті - розглянути і проаналізувати основні проблеми соціалізації школярів в умовах функціонування дитячого музичного колективу.

Соціалізація є суспільним процесом. По-перше, це є залучення індивіда в систему суспільних стосунків, по-друге, це формування його соціального досвіду, а також становлення та розвиток особистості.

Проблема соціально-культурного розвитку та виховання дітей шкільного віку засобами музичного мистецтва висвітлює вагомі протиріччя між внутрішньою потребою у набутті соціального досвіду, потребою мати однодумців, бути визнаним серед ровесників, в самореалізації та між відсутністю оптимальних сприятливих умов, які забезпечили би задоволення визначених потреб дітей у межах їх шкільного та побутового існування.

Процеси соціалізації дитини в творчому колективі вивчали І. Загарницька [2] , А. Капська [7] та інші науковці. Особливу увагу щодо моделі музичної обдарованості і здібностей дітей привертають дослідження О. Горожанкіної [1], Ф. Монкса [6]. Сучасні фестивальні тенденції стали предметом вивченняТ. Зінської [3], М. Крипчука [4], Г. Хрома [8] та ін.

Проблема соціалізації школярів в умовах дитячого музичного колективу $є$ предметом дослідження багатьох вчених і практиків в галузі педагогічної, психологічної науки, вікової 
психології, соціальної психології, загальної педагогіки, музикознавців. Так, А. Мудрик велику увагу приділяє вивченню питань соціалізації у контексті поведінки дитини у відносинах із сім'єю, колективом, суспільством. Г. Гандзілевська досліджувала питання самореалізації в учнівському колективі обдарованих школярів. Н. Корпач розглядає соціалізацію в розвитку особистості підлітка в творчій діяльності у дитячих організаціях різних типів. Питання формування комунікативних здібностей в процесі позашкільної діяльності знаходимо у працях Т. Щербакової, особливості колективного творчого виховання І.Іванова.

Недостатня розробленість проблеми соціально-культурного розвитку та виховання школярів засобами мистецтва, у тому числі музичного, в культурологічній, мистецтвознавчій, соціальній, психолого-педагогічній та методичній літературі свідчить про існування протиріччя: 3 одного боку, школярі мають велику потребу в комунікації саме 3 ровесниками, підвищенні самооцінки за рахунок власних публічних досягнень, самовираження тощо, з іншого - організація навчальновиховного процесу в загальноосвітній школі, спрямована, насамперед, на засвоєння учнями визначеного програмою навчання об'єму знань 3 певних дисциплін. На наше переконання, нерозуміння повною мірою вчителями-практиками великої ролі мистецтва в процесі соціальнокультурного розвитку особистості дитини, особливо в підлітковому віці, є первинним джерелом існування вказаного протиріччя.

Особливе місце в процесі соціально-культурного розвитку особистості дітей шкільного віку, передусім підлітків, займають позашкільні навчальні заклади (музичні школи, художні школи, школи мистецтв) та позашкільні заклади культури (клуби, будинки культури, Палаци культури, центри дитячої та юнацької творчості та ін.).

Водночас, існує певна проблема, прихована в процесі підготовки керівників аматорських музичних колективів, яка не передбачає формування необхідних знань, вмінь та навичок стосовно соціокультурного розвитку особистості в майбутній професійній діяльності. Тож, необізнаність музичних керівників, не усвідомлення ними необхідності та важливості соціально-культурного розвитку особистості дітей шкільного віку свідчить про відсутність готовності їх здійснювати художньо-педагогічний супровід визначеного процесу в умовах музичної діяльності.

Музична діяльність створює найбільш сприятливі умови для організованого соціального досвіду. У цьому контексті, як визначає І. Загарницька, «соціалізація дитини обумовлена вагомістю впливу на цей процес низки факторів. Серед них, безперечно, провідне місце належить сім'ї, адже для дитини головними трансляторами соціальних і культурних цінностей були і залишаються батьки» [2, с. 43], «досить вагоме місце у цьому процесі посідають і засоби масової інформації, які поширюють наукові знання і культуру, організовують розваги, формують відповідні соціальні уявлення та орієнтації особистості у самоствердженні та емоційній розрядці» [2, с. 44].

Діє чимало факторів соціалізації дітей, які мають різні основи (соціальні, мистецтвознавчі, педагогічні; об'єктивні та суб'єктивні; внутрішні та зовнішні; керовані та некеровані; постійні, тимчасові тощо). Вчені визначили наступні види соціалізації: стихійна - відбувається внаслідок впливу на особистість різноманітних, спеціально не створених обставин суспільного життя; відносно спрямована, що має за мету організацію в суспільстві певних передумов, які впливають на розвиток та життєвих шлях особистості; соціально - контрольована, яка $є$ організованою передачею соціального досвіду особистості та розвитку її потенційних можливостей [7].

У цьому процесі важливим $є$ знання соціально-психологічних та соціально-педагогічних механізмів соціалізації що впливають на дитину. До соціально-педагогічних механізмів відносять традиційні: засвоєння людиною норм, зразків поведінки, поглядів, стереотипів, які властиві іiі найближчому оточенню (сім'я, родичі, друзі), та інституціональні, які функціонують у процесі взаємодії людини 3 інститутами суспільства та різноманітними організаціями, а також засобами масової інформації.

Найбільш сприятливими, на наш погляд, умовами соціалізації молодших школярів $\epsilon$ відносини з ровесниками, завдяки яким формуються соціальні уявлення, визначається соціальна позиція дитини, засвоюється нормативний аспект відносин. А головне - саме в цей період відбувається набуття соціального досвіду.

У цьому контексті, дитячий музичний колектив $є$ оптимальним середовищем для виявлення та актуалізації творчого потенціалу кожного учасника, набуття досвіду творчої співпраці, збагачення соціального досвіду не тільки у спілкуванні та взаємодії, але і в різноманітних програшних ситуаціях, 
пошуку шляхів вирішення проблеми при втіленні художніх образів та сценічної взаємодії. Так, можна стверджувати, що всі ці складові активно впливають на обдарованість дитини.

Німецький вчений Ф. Монкс та його співавтор, консультант по проблемам обдарованості I. Іпенбург, автори книги «Обдаровані діти» запропонували свою багатофакторну модель обдарованості, яка складається з трьох особистісних компонентів, основою яких $є:$ інтелектуальні здібності, креативність і мотивація, та трьох факторів середовища, в основі яких є сім'я, школа, ровесники. Дослідники вважають, що тільки при взаємодії та позитивному впливі цих факторів, можливий розвиток обдарованості та його прояви у формі високих досягнень. Авторі підкреслюють, що обдарованість $є$ складним та багатогранним поняттям. Вчені констатують на основі джерела федерального управління освіти Америки, що висока обдарованість проявляється у чотирьох основних формах, а саме: інтелект, креативність, обдарованість у сфері мистецтва та соціальна обдарованість. Однак, до цих чотирьох, автори добавили ще й п'яту - мудрість. Саме мудрість можна вважати, на думку вчених, однією із форм прояву обдарованості [6].

У свою чергу, глядацька культура $є$ вихідним, базовим компонентом соціально-культурного розвитку школярів засобами музичного мистецтва, формування якого спрямовується на оволодіння двома векторами: вміння актуалізувати власну емоційну сферу з метою збагачення змісту, який закладений художником у твір сценічного мистецтва; виникнення постійної потреби аналізувати, переосмислювати побачене та почуте в музичному колективі, долучити враження від твору до свого естетичного досвіду, культурного багажу.

Важливий фактор, який впливає на становлення особистості дитини в колективі, - це розвиток іiі музичних здібностей, які спрямовані на «формування художньо-естетичного досвіду та виконавської культури, що забезпечує досягнення найкращого результату у сприйнятті, розумінні, емоційному та інтелектуальному пізнанні музичного мистецтва, всебічний розвиток індивідуальних якостей та музичних здібностей кожного суб'єкта навчання, можливість його самореалізації у музично-виконавській творчості» [5, с. 16].

3 урахуванням вікових особливостей молодших школярів,розвиток їх музично-творчих здібностей здійснюється на основі ігрової діяльності, що дозволяє створювати умови для більш повної реалізації творчого потенціалу дітей. В ігрових ситуаціях моделюються якості, необхідні для розвитку загальних творчих та музичних здібностей дітей, виконавських навичок. Заняття перетворюються в єдиний динамічний та насичений творчий процес. Саме цей вид діяльності дозволяє підсилити вирішення творчих завдань та більш активно досягати творчих результатів.

Роль керівника дитячого музичного колективу в процесі соціально-культурного розвитку школярів полягає у наступних етапах: формування внутрішньої потреби у продуктивній творчій співпраці кожного учасника музичного об'єднання; зростання рівня соціального досвіду міжособистісного спілкування та вирішення проблемних ситуацій в колективі на основі власного прикладу; збагачення соціальної практики за рахунок вірно підібраного музичного матеріалу як в процесі занять, так і вибір відповідного репертуару загалом; створення необхідних умов для самовираження, самореалізації шляхом оволодіння різним репертуаром; стимулювання творчої активності та реалізацію потреби у визнанні серед ровесників у процесі участі у творчих музичних фестивалях, конкурсах і т. д.

Здобуття незалежності сприяло розширенню міжнародних контактів та використання закордонного досвіду проведення фестивалів в Україні. Разом 3 тим розширюється аудиторія фестивалів: окрім фестивалів класичної музики виникають розраховані на більш масову аудиторію - фестивалі-конкурси, дитячого естрадного мистецтва. Г. Хрома наголошує, що в цьому процесі «проходить процес соціалізації особистості (який починається інстинктивно й проходить стихійно), що впливає на формування смаків (музичних, естетичних і т. д.), допомагає прищепити та закріпити моральні цінності [8]. Сьогодні, аналізуючи сучасні дитячі музичні фестивалі, правомірно розглядати їх вже не як одиничні утворення, а такі, що постійно розвиваються, як художнє явище, як активно функціонуючу систему, невід'ємну частину сучасної культури України. «Соціодинамічні процеси в музичній культурі, зворотні зв'язки між тими, хто творить, виконує, та тими, хто сприймає різні види музичного мистецтва у функціонуванні комунікативної системи, виявляють унікальність музичного мистецтва як явища соціокультурного простору» [3, с. 385].

Основними чинниками, які сприяють розвитку фестивального руху в Україні стали загальні процеси культурної самоідентифікації й регіоналізації. Найпопулярнішими стають наступні дитячі фестивальні заходи: Міжнародний фестиваль-конкурс вокального мистецтва «Зоряні октави» 
(м. Київ), Міжнародний фестиваль дитячої творчості «Золотий лелека» (с. Рибаківка, Миколаївської обл.), Міжнародний фестиваль-конкурс мистецтв «Джерело надій» (м. Одеса), Міжнародний фестиваль-конкурс «Чорноморський бриз» (м. Одеса), Міжнародний фестиваль-конкурс мистецтв «Зірковий грамофон талантів» (м. Львів), Міжнародний фестиваль молодих виконавців сучасної української пісні «Молода Галичина» (м. Новояворівськ, Львівської обл.), Міжнародний фестиваль сучасної пісні і танцю ім. Андрія Гріги «Кришталеві грона» (м. Виноградів, Закарпатської обл.), Всеукраїнський фестиваль-конкурс мистецтв «Юні таланти України» (м. Львів), дитячий музичний фестиваль «Чарівний світ» (м. Черкаси).

Фестиваль дає можливість обдарованим дітям розкрити свої здібності, відкрити дорогу у світ мистецтва та представляє зріз сучасного українського мистецтва, найбільш актуальні його прояви i характерні особливості. О. Горожанкіна розглядає музично-творчі здібності як комплексне утворення, розвиток яких залежить від рівнів сформованості загального інтелекту особистості, музичного мислення, здатності до емоційного реагування на музику, здібності до інтерпретації та імпровізації при мінімумі репродуктивної і максимумі продуктивної діяльності [1].

Основна мета дитячого фестивального музичного руху:

- популяризація вокального мистецтва, народної пісенної творчості, кращих зразків українського фольклору, народної, академічної, джазової, сучасної естрадної пісні та культури, фольклору та пісенного мистецтва національних меншин, що проживають в Україні;

- сприяння розвитку та реалізації творчих ініціатив молодих митців;

- виявлення і підтримка творчих та інтелектуальних інтересів дітей, юнацтва;

- виховання у молодого покоління любові до пісенного мистецтва, толерантного ставлення до культурних надбань України.

Сучасні дитячі музичні фестивалі є справжнім мистецьким твором із стилістикою змішаного типу; культурною формою, що віддзеркалює регіональні потреби як загальнонаціональні, тобто на концептуальному світоглядному рівні, і водночас дозволяє не втратити реальних зв'язків із середовищем, на яке спрямоване [4, с. 153].

Головне завдання музичного керівника в художньо-педагогічному процесі соціальнокультурного розвитку школярів - це створення сприятливого мікроклімату функціонування творчого об'єднання, забезпечення змістовно насиченого спілкування виконавців, систематичний моніторинг творчих досягнень та поразок як колективу, так і кожного учасника, планування та корекція стратегії художньо-педагогічного супроводу, формування адекватної самооцінки та підтримка зацікавленості у творчій діяльності школярів на основі загального аналізу певних позитивних та негативних процесів, впровадження та підтримка цікавих, корисних ритуалів і традицій.

Невід'ємним компонентом і фактором соціально-культурного розвитку особистості дитини $\epsilon$ креативність. Художньо-педагогічний супровід розвитку творчих здібностей особистості дитини в умовах музичного колективу повинен забезпечуватись соціокультурною діяльністю, що передбачає використання наступної системи культуротворчих технологій: арт-менеджмент технології, мобільні технології, технології творчого пошуку, технології художнього втілення.

Дослідження системи культуротворчих технологій та ії педагогічного потенціалу в процесі розвитку творчих здібностей дітей шкільного віку в умовах музичного колективу буде подальшим напрямом дослідження, бо проблема соціалізації школярів в умовах дитячого музичного колективу в сучасних умовах потребує обгрунтування у музично-педагогічному та культурологічному просторі.

\section{ЛIТЕРАТУРА}

1. Горожанкіна О. Ю. Розвиток музично-творчих здібностей учнів в процесі навчання в фортепіанному гуртку / О. Ю. Горожанкіна. [Електронний ресурс] - Режим доступу: http://naukajournal.org/index.php/naukajournal/article/view/124/190

2. Загарницька I. I. Соціалізація дитини: сутність, фактори, технології / I. I. Загарницька // Нова парадигма: журнал наук. праць; гол. ред. В. П. Бех. - К., 2011. - Вип. 104. - С. 41-51.

3. Зінська Т. В. Музичні конкурси та фестивалі в контексті соціокультурного проектування в Україні кінця XX - початку XXI століття / T. В. Зінська // Професійна мистецька освіта і художня культура: виклики XXI століття: матеріали II Міжнарод. наук.-практ. конф., (Київ, 14-15 квітня 2016 p.). - K., 2016. - C. 384-395.

4. Крипчук М. В. Розвиток сучасних фестивалів мистецтв на Луганщині початку XXI століття / М. В. Крипчук // Мистецтвознавчі записки: зб. наук. праць. - К.: Міленіум, 2013. - Вип. 24. - С. 148-153. 
5. Ліпська С. Л. Методичні засади удосконалення музично-виконавської підготовки учнів в умовах позашкільної спеціалізованої освіти: автореф. дис. ... канд. пед. наук: 13.00.02 / С. Л. Ліпська. - К., 2007. - 23 с.

6. Монкс Ф. Одарённые дети; пер. с голл. А. В. Белопольский. - М.: Когито-Центр, 2014. - 130 с.

7. Соціальна педагогіка: підручник; за ред. А. Й. Капської. - К.: Центр учбової літератури, 2011 - 488 с.

8. Хрома Г. Деякі особливості сучасних молодіжних фестивалів / Г. Хрома // Матеріали до українського мистецтвознавства: зб. наук. праць.- 2003. - Вип. 3. - [Електронний ресурс] - Режим доступу: http://etno.kyiv.uar.net/vyd/matmyst/2003/N3/Art40.htm.

\section{REFERENCES}

1. Gorozhankina O. Y. Rozvytok muzychno-tvorchykh zdibnostei uchniv $v$ protsesi navchannia $v$ fortepiannomu gurtku [The development of musical and creative abilities of students during piano classes]. Naukovyj ohliad, 2014, vol. 3, num. 1. Available at: http://naukajournal.org/index.php/naukajournal/article/view/124/190.

2. Zagarnytska I. I. Sotsializatsiia dytyny: sutnist, faktory, tekhnologii [Child socialization: meaning, factors, technology]. Nova paradyhma, Kyiv, 2011, vol. 104, pp. 41-51.

3. Zinska T. V. Muzychni konkursy ta festyvali v konteksti sotsiokulturnoho proektuvannia v Ukraini kintsia $X X$ - pochatku XXI stolittiia [Music contests and festivals in the context of sociocultural projecting in Ukraine in late XX - early XXI century]. Profesiina mystetska osvita i khudozhnia kultura: vyklyky XXI stolittia, Kyiv, 2016, pp. 384-395.

4. Krypchuk M. V. Rozvytok suchasnykh festyvaliv mystetstv na Luhanshchyni pochatku XXI stolittia [The development of modern festivals of mysticism in the Luhansk region in the 21st century]. Mystetstvoznavchi zapysky, Kyiv, 2013, vol. 24, pp. 148-153.

5. Lipska S. L. Metodychni zasady udoskonalennia muzychno-vykonavskoi pidhotovky uchniv $v$ umovakh pozashkilnoi spetsializovanoi osvity. Avtoref., kand. ped. nauk [Methodical bases of the improvement of training students' musical performance in terms of non-formal special education. Phd (ped. sci.) abs.], Kyiv, 2007. 23 p.

6. Monks F., Ypenburg Y. Odarionnyie deti [Gifted children], Moscow, Kogito-Centre Publ., 2014. 130 p.

7. Kapska A. J. (Ed.) Socialna pedagogika [Social pedagogy], Kyiv, Centr uchbovoi literatury, 2011. 488 p.

8. Khroma G. Deiaki osoblyvosti suchasnykh molodizhnykh festyvaliv [Features of contemporary youth festivals]. Materialy do ukrainskoho mystetstvoznavstva, 2003, vol. 3. Available at: http://etno.kyiv.uar.net/vyd/matmyst/2003/N3/Art40.htm.

ТЕТЯНА РИБАК

rb.sisters.999@yandex.ua аспірантка,

Хмельницька гуманітарно-педагогічна академія м. Хмельницький, вул. Проскурівського Підпілля, 139

\section{АИААКТИЧНИЙ ПОТЕНЦІАА ВИХОВАННЯ УЧНІВ ЗАСОБАМИ ХУАОЖНЬОГО САОВА В ОСВITHIX УСТАНОВАХ ЗАХІАНОЇ УКРАЇНСЬКОЇ АІАСПОРИ}

Проаналізовано дидактичний потенціал виховання учнів в освітніх установах діаспори засобами художнього слова. Акиентовано на функиії української літератури, яка сприяє формуванню розвиненої особистості, ї̈ підготовці до свідомої та активної трудової діяльності. 3'ясовано, щео, занурюючись в систему художнього світу, учень навчається із життя головних позитивних персонажів, як треба жити в суспільстві і принести йому найбільшу користь, адже підручники і посібники з рідної літератури, читанки в діаспорі створюють основу для вивчення дітьми поведінки свідомості. Доведено, щчо потужний морально-виховний і художньо-естетичний потениіал української словесності реалізується в підручниках західного українського зарубіжжя метою етнокультурного збагачення школярів і насамперед формування національної свідомості украӥнських дітей та активного вибору ї̈ цінностей. Встановлено, щчо дидактичний потенціал виховання учнів засобами художнього слова уможливлює прищепити любов до рідної мови, Украӥни і изим сповільнює процес асимілящії в іноземному середовищі.

Ключові слова: виховання, дидактичний потенціал, читанка, украйнська література, художне слово, навчання. 